\title{
The politics of moral panic: Anthropology of mass- panicking processes of contemporary Sri Lanka
}

\author{
A. Sarath Ananda \\ Department of Social Science, Sabaragamuwa University of Sri Lanka, Sri Lanka
}

\begin{abstract}
Sri Lanka society is an appropriate arena of research to the nature of moral engineering and moral enterprising for unending power struggle of supremacy seekers and pressure groups. The political as well as cultural elite-sponsored moral panics that come from many forms that based on semi-authentic or fault factors makes a huge damage to the social order of the nation. The long term disturbance to the nation development, social integrity and cultural ethical codes is immeasurable. This article deliberates over selected cases such as debate over chronicle kidney diseases, food poisoning, DCD, satirizing pills and satirizing surgery panics appeared in the contemporary history in Sri Lanka. The basic objective of this research is building a sociological discourse on the prevailed reality of the concurrent socio-political structure and revealing its effectives on Sri Lankan society. This paper that has been employed enclosing the discourse building a literary discourse on the concept of moral panic such as, reviewing worldwide experiences on masspanicking and the application these concepts to the concurrent Sri Lankan socio-political context. Primary data were extracted by selected newspaper articles, recorded public speeches made by influential individuals, blog reports, research reports and public acts regarding various issues related in the thematic area of this research. This study also has been built largely on the contour of secondary literature. Sociological as well as philosophical perceptions developed in multiple dimension on moral panic that has been used as tools of context analysis. Finally, this paper concludes the politicians, cultural elites and some pressure groups that seek contentment of their hidden political agendas shown as vital actors as moral engineers and moral entrepreneurs responsible for mass panicking. So-called mass media and uncensored social media users knowingly or unknowingly has carried out the needs of those groups.
\end{abstract}

Keywords: Moral Panic, Sri Lanka, Glyphosate, DCD, satirizing pills, satirizing surgery

\section{INTRODUCTION}

$\mathrm{U}$ nderstanding the political behavior of an individual may be complex and imperceptible. When it becomes a social phenomenon, the complexity may be rather cumulative (Amenta et al. 2010, Bide 2015, Dalton R.J. and Hans-Dieter 2013). Sometimes, a sudden and inescapable incident would be a cause of the turning point of the entire political system in a country. At the time absence of powerful natural cause, a politically fascinated group might be intervene creating controversial as well as effective dialogue that might be useful as a tool deteriorating yet a government or a ruling political system. This nature is apparently frequent in great degree in the Sri Lankan political system. In accordance, the factor of mass-fear (moral panic) seems to play a remarkable role that manipulating Sri Lankan politics. Though the necessity, shape and the magnitude of application is varying accordingly, the circumstance seems being repeated. The common experience of operating the panicking is usually accelerated at the period of the precondition of a general election. All parties of the contest are responsible for spreading panics against each other. In many times, certain political parties, and pressure or agitation groups successfully used moral panics as a device of tarnishing the rivals or/and purposing the simultaneous building of self-images. Though the situation may be common and equal to all countries, some Sri Lankan experiences seems to be interesting sociologically and anthropologically.

The concept of 'moral panic' is initially introduced by late South African sociologist Stanley Cohen (1942- 2013). Later, many Sociologists and Anthropologists have contributed developing it with providing subsequent studies with comprehensive worldwide examples. As the founder of the concept, Cohen built his theory of moral panic based on his study of public reaction in England to fight between the "mod" and "rocker" youth subcultures that was popular in 1960s and 70s. Throughout his study, Cohen observed the behaviour of these young groups and media and public reaction to them. On the words of Cohen;

"Calling something a 'moral panic' does not imply that this something does not exist or happened at all and that reaction is based on fantasy, hysteria, delusion and illusion or being duped by the powerful. Two related assumptions, though require attention - that the attribution of the moral panic label means that the 'things' extend and significance has been exaggerated (a) in itself (compared with other more reliable valued and objective sources) and/or (b) compared with other, more serious problems. This labeling derived from willful refusal by liberals, radicals and leftists to take public anxieties seriously. Instead, they are furthering a politically correct agenda: to downgrade traditional rules and moral concerns" (Cohen, 2002: vii).

Goode and Ben-Yehuda (1994) other prominent propagators of the concept concerned that made a good effort to theoretically scrutinize on youth drug use in Israel and the United States in the 1980s. These authors have classified three accounts that to be responsible for construct panicking such as grassroots (general publics including mass media), elitist moral engineers and interest groups.

Although, both Cohen and Yehuda basically limited over seven major areas such as AIDS, child abuse, drugs, 
immigration, media violence, street violence and youth violence (Critch, 2008), that particularly based on the accounts of religious, spiritual and psychological perspectives, many others have elaborated this concept in using various other perspectives. Rocheron and Linne (1989) claim that one of AIDS prevention programmes launched in United Kingdom (UK) with panicking of public moral. The same argument comes from Holland et al. (1990). Although, these critical approaches are being coming from different disciplines, fields and perspectives, some common factors on moral panic seem to be appeared in such as: (1) Existing social unrest over partly true or entirely false propagation, (2) Spreading panic over the society, (3) Considerably taking part by the media in terms of circulation of the particular issue, (4) Interference of political and other cultural elites and (5) Commercially advantaged by particular parties.

As extending of Goode and Ben-Yehuda's ideas Hill (2001) elaborates the role of moral enterprising of elite-engineers and interest groups that how the elites and political pressure groups purposefully use social panic to achieve their political goals in Singapore in 1980s. Since the Singaporean government identified the uprising religiosity among groups as a threat to the on-going 'Singaporean system' and maintaining social harmony within communities, the ruling elites sponsored to construct initially a mass panic on it and then took policy action to control it in various aspects. According to Hill, there were three main arguments came from Singaporean estate authority such as, the uprising religious movements may be threaten in conflicting loyalty with the estate and Islam, the proselytizing process over growing influence of evangelical Christianity among Chinese and finally, the growing social activists form Catholism and its probable hidden link with 'Marxist conspiracy'. Moreover, the moral enterprising and moral engineering against religiosity and spirituality has been a common involvement in many societies worldwide over the history (Ugwuokeet al., 2016; Faundes, 2019). Within this parameters, the concept of moral panic seems to be drastically useful tool to evaluate the concurrent political behaviour of the Sri Lankan society.

\section{OBJECTIVES AND METHODOLOGY}

The basic objective of this research is building a sociological discourse on the triumphing reality of the concurrent sociopolitical structure and revealing its effectives on Sri Lankan society. Among prime objectives this paper that has been employed enclosing the discourse in terms of building a literary discourse on the concept of moral panic such as, reviewing worldwide experiences on mass-panicking and the application these concepts to the concurrent Sri Lankan sociopolitical context. To make realize these broader goals this study has been aligned on both primary and secondary sources. Primary data were extracted by the use of context analysis. Selected newspaper articles, recorded public speeches made by influential individuals, blog reports, research reports and public acts regarding various issues related to the thematic area of this research. This study also has been built largely on the contour of secondary literature.
Sociological as well as philosophical perceptions that have been developed in multiple dimensions on moral panic that has been used as tools of context analysis.

\section{RESULTS AND DISCUSSION}

The use of moral panic for the purpose of social control has been a structuralized cultural factor for a long period in Sri Lanka. Sometimes, the panicking circumstance may be beginning from the cradle to have a break from torrential lament of the kid or the time of rejecting food. Often the parents may uses the imagined horror physical that calls "Happa" that may have been almost all Sri Lankan experienced in their childhood ${ }^{1}$. When kids are being grown, the old "Happa" may be diminished though, the same mechanism might be continued sometimes associate with elaborations. For instance, either avoiding unauthorized tours of their children or preventing exceed them from their controllable neighboring proximity the parents used the frighten story on the "Billa" (a strange human figure who abduct children) which is articulated in different forms. The fabrication about "Sanyasi billa" who comes to collect children that behave lonely has been populated in 70/80 decades or sometimes further prior. The imagined figure of Sanyasi billa may delineate as a man with dirty and fully beard face and a large sack in-hand ${ }^{2}$. Despite the fact, there is no clear explanation for the cause of kidnapping, the billas secretly come to villages and escape keeping abducted children in their long sacks. Therefore, these billa is also called as "goni billa" (gunny-sack man) by peasants. Sometimes, the image of the old Jujaka that is depicted in murals of temples as said by the popular lore - Wessanthara jathaka of the Buddhist literature may have been influenced to construct the imaginary figure of 'sack man' vice- versa. Comparatively based on reliable factors of 'child abduction' is the kidnapping of children to be employed as compelling labour in the dried-fish industry of so-cold unknown remote islands ${ }^{3}$. Although, the sources of these folk tales is uncertain, they have been successfully used by parents to control their 'naughty children". Another identical rumour has been experienced this author regarding a woman who was killed as a result of snake biting which was inhabited in her napkin. This gossip delineated that the snake (The 'blood-wiper' (lemapila or nidi-mapila $)^{4}$ believed to be habituated sucking animal blood) has been hidden in unkempt clothes that used as alternative napkin by rural women in their menstruation

\footnotetext{
${ }^{1}$ This term has been defined as serpent or small crawling creature by P.B. Meegaskumbura. (See: Meegaskumbura, P.B. (1978) WORD: Journal of the International Linguistic Association, Vol. 31, 3 (1978) New York, 287-309 (Quoted from Prof. P.B. meegaskumbura Felicitation Volume (Ed.) Sudeva, D. Wimalasara, P. and Siri Sudhamma A. (2020) Dehivala, Vidarshana, P: 342)).

${ }^{2}$ The term 'Sanyasi' (Sometimes locally pronounced as 'Thannasi or Sannasi') may be originated on the emphasis of fourth out of the ideal Hindus' four-phased of life circle such as Brahmachari, Gruhastha, Vanaprastha and Sanyasi. The Sanyasi period represents the elderly period depending on the own children or the others

Trafficking of Persons Report 2010, 10 ${ }^{\text {th }}$ Edition, (p.302) www.state.gov/tip.http://books.google.lk//books?isbn=1437937160

${ }^{4}$ scientifically called Boiga Celonensis
} 
period. The same rumor came in another version with different form but same context. This incident has been taken placed in a garment factory. According to the script, a workerwoman in a garment factory has been fainted several times followed by feeling sleepy at preliminary stages. So the fellow-workers have immediately taken action to admit her to the hospital, she was not fortunate to remain. The forensic medical test finally took place and revealed that a 'blood wiper' has been living in her pads. So the entire day has been gloomed to the whole garment factory.

With regards to the first may be a common and intrinsic action of elders to control their kids and the second may be concluded as a mere inoffensive action that is usually taken by rural parents proceeding the magnitude of their practical knowledge controlling own children. Moreover, it can be functionally generalized as a primitive attempt to acknowledge future hazards and uncertainties to their children by parents at the initial stages at the long-standing socialization process. Even within these episodes, the third can be taken as a slight-significant, comparatively reliable socially embedded rumor. Despite not having a believable scientific base, it shows as a proportionately politically sounds social reality. It essentially depicts the socially and culturally implanted character of lower-middle class, the nature of Sri Lankan female's socio-economic status and vulnerability of primary healthcare facilities of their day- to-day life. Although, all these examples are consistently considered as myths that could be critical of those situations, in the view of the fact that, recently emerged horrific rumors seems remarkably associate with various phase of hidden agendas. There has been substantial socially impacted moral panic incidents happened in the adjacent history of Sri Lanka. For instance, 'panic of grease yakaa (Demon) (rumbled around 2009/10) 'panic of glyphosate' (contentious in 2015 onwards) the 'panic of melamine' in milk powder (peaked in 2013/17), and 'panic of sterilization pills' (derived in 2015s and drastically highlighted in the late 2019) are some of them. While some are gradually disappeared during certain situations and others yet to be apparent with being subjected in various moderations. There is adequate possibility of popularizing those that are relatively structuralized panics or those which to be generated as newer elaborations in future. Mostly these are either based on weaker rationalities or highly exaggerated by rumors or sometimes derived from entirely false factors. Yet, the rapidity of their publishing and social impact cannot be underestimated. Thus, the present attempt is making an overview of selected recent and ongoing panics in Sri Lanka

In Sri Lankan history, as afore said, the moral panic has been used as a useful tool of both political and cultural elites to control their subjects. Although, the defining of political elites may not be essential, the identification cultural elites possibly may important in this discussion. While all religious leaders such as mainly Buddhist and in some extent Hindu, Muslim and Christian are responsible for bearing the national elitists, other local medical practitioners, spiritual healers (kapurala, kattadia) and some socially significant professionals including principals (including teachers) of local schools tend to be influential figures determine day to day cultural action of the general public. Among these, the clerical factor is usually universal actors of enterprising panic among their followers delineating the relation of sin and next life. The medical practitioners and other anchoring professionals may be comparatively depend on moral engineering on the purpose of fulfilling obligations devoted to their service. In contrast the moral engineers that stamped from traditional roots of myths and believes may have been rather crucial in shaping the sole innate factor of general public in Sri Lanka. So, the role and effect of supernatural healers such as kapurala and kattadia is tremendously decisive in this regards (Waxler, 1976; 1977, Obeyesekara, 1977).

\section{Panic of Glyphosate Use}

The debate over glyphosate is the most powerful panic over all ranks of the society that sometimes has been the cause of underneath every other ongoing social issues. The main reason of it is the consisting of several patriotic chauvinists in the anti-glyphosate campaign. Academics such as physician Channa Jayasumana (and his team), and politician Athuraliye Ratana thera were significant propagators of this movement. The initial derivation of this took place followed by revealing high rates of kidney patients from agricultural based NorthCentral dry zone in Sri Lanka. The prevalence of CKDu is estimated that 15.2-29.9 percent of population in the Dry one districts in Sri Lanka (Rajapaksha et al., 2016). Even though, there was a whispering of possible correlation over high rates of kidney disease and contaminated environment as a result of over-using agro-chemicals, it has been turning to a hullabaloo at the beginning glyphosate of 2010s. The terminology, 'Chronicle Kidney Disease of Unknown etiology' (CKDu) that was popular among media, academics and other social activists created a specific dread. In particular the term 'unknown' was the cause of generating additional anxiety on it in the society. A number of researches in different perspectives such as medical (Jayalal, 2015), Geological (Cooray et al. 2019), Geographical (Jayasekara et al. 2013), Agricultural (Mendley, 2019), economical and sociological (Bandarage, 2013) have been conducted for the purposing of finding the ' $\mathrm{X}$ factor'.

Although, there was no final conclusion at the beginning, many researches; particularly sociological (De Silva et al., 2017) have built uncertain hypothesis and focused anxious judgments towards prolong use of agro-chemicals in agriculture in the Rajarata area. The profound or sometimes over use of agro-chemicals such as herbicide, patricide and fertilization have been vastly institutionalized in the Dry Zone peasant life. The then government paid its attention on the issue and the parliament took action to appoint a special team for consultancy to the parliament on $20^{\text {th }}$ November 2012. The consultants stepped forward to produce a cabinet paper with incorporating 14 recommendation. The most significant five statements as are the followings: 1) to make quality control over importing pesticide and herbicides to Sri Lanka, 2) to 
suspend distribution propanol glyphosate and clorox ropes carbofuran pesticides in $\mathrm{CKDu}$ prevailed areas, 3) banning advertising of pesticide and herbicide, 4) Supplying quality drinking water to relevant region, and 5) to introduce $10 \%$ taxation over import pesticide and herbicide. The government endeavored to implement all recommendations twice in December 2013 and March 2014 but failed as a result of various interventions. However, the official attention of relevant authorities over the issue and the high attention of Medias on it caused grown-up apprehension on the use of agro chemicals and food poisoning amongst the general public.

The revelation of Jayasumana et al. (2015) that agricultural productions including rice in Rajarata area is contained arsenic which to be caused of CKDu of people of prevailing region provided an academic tone to the panic. Anybody may imagine the gravity of public anxiety when the rice has been the traditionally, culturally as well as economically structuralized staple food of Island-wide ethnic groups. Although, the paper was published in the aforesaid year, the local media has given the publicity even in the early periods. This statement has been a wonderful backup to use as a 'placard' to the ongoing political propagation of leading patriotic agents. Ven. Athuraliye Ratana made a immense sound and there was a huge controversy within parliament parallel to the cabinet reshuffling took place in $26^{\text {th }}$ March 2018 on the use of glyphosate as an herbicide in the agricultural industry. At the same day the then president Mithreepala Sirisena took step fulfilling balloting assurance to parliamentarian Ratana thera to ban glyphosate.

\section{Media debate over glyphosate use}

There was a massive controversy over the decision of glyphosate banning by the government that has been directed to a media based debate between pro and anti-glyphosate combatants which is even continued up to now. Patriotic antiglyphosate campaigners profoundly pronounced terms such as sustainable agriculture, uncontaminated environment, indigenous knowledge, 'Western conspiracy' etc. whereas, pro-glyphosate propagators ridiculously condemned with the use of strong arguments against to so-called 'island mentality'. For instance, Professor Chandre Dharmawardhana, prominent pro-glyphosate propagator questioned in a media with the title of "Is Sri Lanka a 'killing field' full of toxin where people die of kidney disease?" reported by Colombo Telegraph $15^{\text {th }}$ January $2018^{5}$. Quote him; "Killing field is an attractive slogan for those foreign agents who compete with Sri Lankan agricultural products. It is also a useful cry for those who wants to destroy the rural landscape and replace and replace an urban mega polis". The term 'mega polis' seems to be a direct attack to the then parliament minister who initiated mega polis development project while representing Sinhala-Buddhist political party 'Jathika Hela Urumaya'. Dharmawardhana also continued his argument writing to

https://www.colombotelegraph.com/index.php/is-sri-lanka-a-killing-fieldfull-of-toxins-where-people-die-of-chronic-disease/
Sunday Observer newspaper in $10^{\text {th }}$ March $2018^{6}$, "People become "heroic" and raise fear against glyphosate which has become a surrogate for attacking a big multinational namely Monsanto!" Moreover, he stated "This was only state as a "hypothesis" but sold to the public as a proven fact, even though there is not one iota of evidence for it. The government is embarrassing unproven claims of anti-science pressure group has banned glyphosate”. According to Colombo Telegraph on $29^{\text {th }}$ May $2015^{7}$, Oliver A. Ileperuma criticized the banning of glyphosate claiming that it is a political action but not scientific reason. Minister Navin Dissanayake who is highly depending on votes from the High Lands plantation sector opposed the act of banning glyphosate as a result of some pressure groups of the own government. He aggressively stated in a media conference on $11^{\text {th }}$ March 2018 demanding that "I don't want to be a 'hero' for the gallery". At the same day, the Chief of the Tea Board in Sri Lanka made a factual description to Sunday Observer stating "Tea production declined to 328.9 million $\mathrm{kg}$ in 2015 compared to 338.0 million $\mathrm{kg}$ recorded in the previous year and it was further plunged to $292.3 \mathrm{~kg}$ million in 2016" Waidyarathna continued the argument writing to the same newspaper on $30^{\text {th }}$ July 2018 under the theme "Blind men and "glyphosate elephant" emphasizing the famous saying of Hippocratic, the founder pharmacology over 600 B.C. ago "All substance are poisons". He further stated "The corn famers complain that their pre-plant weed control has short up from Rs. 3000/- to 10,000/- after the glyphosate ban, especially because of the need to uproot Mana grass by mammothy. Eight labor unit required each costing Rs. 1,250/9." Some foreign web pages such as 'Glyphosate Facts: Transparency on Safety Aspects and Use of Glyphosate Confusing Herbicide in Europe ${ }^{10}$, seemed to have paid its careful attention on Sri Lankan parliamentary act against glyphosate during the parallel period. It also judgmentally reported over Sri Lankan government issued restriction on the use of five agricultural pesticides including glyphosate is a political but not supported by scientific evidence (Online access 1.11.2019).

The high tension and anxiety about the use of agro-chemicals and its consequence factor was not only emphasized by political and cultural elites but also this idea was highly legitimated even by aforesaid academics. For instance, as some academics such as Professor Sunil J. Wimalawansa's intervention into this discourse, the anti-glyphosate fracture has been sturdier. Wimalawansa wrote to Sunday Observer at the early stages of the ongoing controversy on $24^{\text {th }}$ November 2013; "The water and food in the certain (CKDu) affected areas is polluted with low levels of toxic heavy metals, cadmium, arsenic and lead as well as with fluoride and toxic

\footnotetext{
http://www.ft.lk/article/634306/ft

${ }^{7}$ https://www.colombotelegraph.com/index.php/banning-glyphosate-forpolitical-not-scientific-reasons/

https://www.historyofceylontea.com/ceylon-publications/ceylon-teaarticles/govt-decides-to-lift-glyphosate-ban-to-rescue-tea-exports.html

${ }^{9} \mathrm{http}: / /$ bizenglish.adaderana.lk/blind-men-and-the-glyphosate-elephant/

${ }^{10} \mathrm{https}: / / \mathrm{www} . \mathrm{glyphosatefacts/en/glyphosate/glyphosate-safe}$
} 
agro-chemicals" ${ }^{\prime 1}$. With the banning of glyphosate, some foreign Medias reported it with inserting Sri Lanka into the list of 10 prominent glyphosate-free nations such as Elsalvador, The Netherlands, Brazil, Argentina, France, Russia, Columbia, Peru, and Mexico ${ }^{12}$ (time.com/2015/08/18). Although, the then president Mithreepala Sirisena took an immediate action to ban glyphosate, the implementation has been extremely vulnerable as a result of heavy pressure from pro-glyphosate combatants from the later period of 2016. However, Ven. Ratana never given up fighting against and his statement on it was reported by Zahrah Imitiaz to the Daily Mirror on $21^{\text {st }}$ September 2016 under the title of "Ban on glyphosate will never be lifted Ven. Ratana Thera" The correspondent has quoted the Ven. Ratana's statement: "Minister Navin Dissanayake cannot being back glyphosate. The ban will never be lifted said JHU MP A. Ratana Thera yesterday as he criticized the minister's promise to lift the ban on glyphosate in order to save tea industry" 13 ". Sugeeswara Senadhira also considered "CKDu is strongly suspected to be due to insecticides, chemical, fertilizer and contaminated water" in Sunday Observer newspaper on $12^{\text {th }}$ March $2017^{14}$. The Sri Lanka Mirror web page on $13^{\text {th }}$ march 2018 made a heading considering that "experts more in favor of glyphosate ban". It revealed Minister Rajitha Senaratne and Dr. Anil Senanayake among the 'other experts' including Ven. Ratana who favored in continued glyphosate banning ${ }^{15}$. President Sirisena again exposed his enthusiasm to ban glyphosate with his declaration of opening of 'poison-free agricultural educational exhibition' under the theme "Toxin-free nation: A wholesome agriculture - a healthy populace - a toxin-free nation at BMICH in $6^{\text {th }}$ March $2018^{16}$.

The anti-glyphosate campaign came into its supreme with the gathering of Polonnaruwa based farmer organization 'Govi Jana Samuluwa' chaired by Kaudulle Jayathissa. According to report of Sunday Leader on $10^{\text {th }}$ March 2018, Kaudulle Jaythissa said "The destruction of the ancient cascade system and introduction of a new irrigation system is somewhat responsible for the environmental problem of the Dry Zone". The Executive Director for the Centre for Environmental Justice (CEJ) Hemantha Vithanage noted based on Central Bank Report 2007 “... The fix price of USD 3.07 for a $50 \mathrm{~kg}$. Bag fertilizer whereas actual prize is over USD 75..." (That shows the bond of the government and the dependency of local farmers on imported artificial fertilizers). Ven. Ratana continued; "We have been over dependent on chemical agriculture. As result we are already faced with many

11

http://archives.sundayobserver.lk/2001/pix/PrintPage.asp?REF=/2013/11/24/ main_Obituaries.asp

12 http://www.it-takes time.com/2015/08/18

13 http://www.dailymirror.lk Daily Mirror on 21st September 2016

${ }^{14} \mathrm{http}$ ://archives.sundayobserver.lk $12^{\text {th }}$ March 2017 glyphosate-ban https://srilankamirror.com/news/4149-experts-more-in-favour-of-

http://www.dailynews.lk/2018/03/07/local/president-opens-poison-freeagricultural-educational-trade-exhibition environmental and health issues. The country has about 50,000 kidney patients, who are mostly farmers and agricultural workers... moreover, there were more than 20,000 people died of kidney failure in the country"17.

\section{Social impact over agro-chemical panic}

The debate over agro-chemical use in the agricultural sector has been pendulant among two different opposition groups for the purpose of their personal agendas, the impact made by the controversy within entire social system cannot be underestimated. On the one hand, the general publics were pushed over to look at all agro-production with their internal distrust. Although, the TV programs conducted by consulting Western and Ayurvedic medical doctors, nutritionists, popular artist all the times of the day and night, the regular pages of day to day newspapers and official awareness programs including school education constantly emphasized the importance of fresh and toxic-free food consumption, the ground reality of the foodstuff industry that shows the features of unescapable trap. According to an editorial of one of the leading Sinhalese newspaper: "Formalin is used to preserve fish, carbide to ripe fruits instantly, multiple pesticide in vegetable, and artificial hormones in chicken, die that coloring vegetable! So, the latest issue, arsenic in rice or the paddy cultivation cannot help without glyphosate!!"18. On the other hand, the active agricultural workers were in a trouble that made by immediate withdrawal of glyphosate from their habituated farming pattern. A plenty of farm lands including chena and paddy cultivation has been abandoned due to lack of labor that to be fought against fast growing weeds without alternative weedicide. Consequently family economy of villagers was dropped and the unemployed village labor flooded towards nearby town and metropolises for seeking any of alternative employments (Marambe, 2019).

In case of peasants, a glyphosate-free agriculture could not be imagined, as aforesaid prolonging addiction on it. Notwithstanding glyphosate has been banned, many incidents were reported that it imported illegally. For instance, the Colombo Page website reported in $23^{\text {rd }}$ September 2017 that 20 feet long glyphosate container was discovered by the Custom Department in the Orugodawatta Container Yard ${ }^{19}$. It further declared 3948 cans of glyphosate containing over 15,000 liter were found in the container. Even though, the banning was strictly implemented, the illegal supply for the demand was not ended. The illegal supply chain tended to find alternative solutions. Consequently the Daily mirror newspaper reported another 'creative manner' of trading under the heading "Cutoms seize 656 kilograms of glyphosate under sacks of green chilies" in $17^{\text {th }}$ November $2017^{20}$. Again, www.hirunews.com reported another incident with the heading of "28,000 kilograms of glyphosate illegally imported into Sri Lanka have been apprehended by Sri Lanka Custom

\footnotetext{
${ }^{17}$ http://www.thesundayleader.lk/

${ }^{18}$ Daily Divaina (2018.03.13)

${ }^{19}$ www.colombopage.com, (Online access 11.02.2018)

${ }^{20}$ (www.dailymirror.com - online access 11.02.2018)
} 
staff" in $12^{\text {th }}$ January $2018^{21}$. Sri Lanka Rupavahini (Television) news revealed yet again 'a container with full of glyphosate seized by Sri Lankan Customs' in $15^{\text {th }}$ March 2018. If we presented few of these as sample incidents, either publicly or covertly an abundantly of similar incidents were happening during this period.

The farmers have found a 'homemade solution' sometimes readers make smile on that they use monosodium glutamate or Ajinomoto acid (MSG) instead as it increase the effect of the weedicide (Sunday Leader $8^{\text {th }}$ November 2018). According to this author's field experience, it would be interesting to consider that farmers were producing a chemical mixture alternative to glyphosate using Ajinomoto, kerosene oil, bath shampoo etc. to fight against fast growing weeds. Although, the effect is somehow of this local production, it reveals how far they have been addicted using glyphosate and indigence of sustainable solution. The same newspaper reported that as a result of people's panic of living CKDu prevailed areas the land value of surrounded zones have increased subsequently. For instance, in Rambana, "before the water project started, one acre of land could be bought with less than Rs. 20,000/and now to buy 20 purchase the client has to pay about Rs. 50,000/-“(Ibid). In Madawachchiya, some people considered that one of the burning issue that they faced as reluctance of people of other areas to get marry with both men and women living in their home lands. This situation has been discussed in another study; it is quoted in their personal sound; "The outsiders are afraid of find spouses from our families, because they thought the spouse may occured kidney disease any time of the post marriage period as well" (Dissanayaka \& De Silva, 2017).

The drinking water was the most demanded consumer item of the Rajarata area. Mineral water bottles were gradually placed in almost all super markets, wholesale spots and retail grocery shops. The people belong to so-called ancient and noble 'hydraulic civilization' or the 'lake-built state' (wew bendi rajyaya) were constrained to depend on plastic water bottles. Many traditional wells and nearly all tube wells in villages were introverted. The laps of village women that detained the traditional water-pots replaced by 4-litre plastic water bottles purchased by neighboring shops. Gradually the water bowsers supplied 'for free' by the government, 'accessible prices' by welfare organizations and 'for attractive amounts' by vendors was a common scenery of the Rajarata area. Various welfare organizations entered into issue providing alternative solutions. Some groups published their initiation welfare project by media entertaining. For instance, within first two weeks of March 2018 the Sunday Observer newspaper only reported different water projects launched by NGOs and welfare groups as are the followings: "The Commercial Bank of Ceylon launched 'Raindrops' Project donating 5000-letre storage water tanks for rain water harvesting to families of Giranduru Kotte area". Its slogan was 'Drink raindrops - prevent from CKDu' (4 ${ }^{\text {th }}$ March Sunday Observer) ${ }^{22} \cdot$ CBO Yudaganawa-Polonnaruwa Water Project and Hayleys Group (Pvt Ltd.) provided Reserve Osmosis Plants (RO) over the Dry Zone (Ibid). The Drinking Water Supplying Project boosted by 'Karuna Trust': An Organization for Human Development released 1000-litre drinking water tanks to CKDu prevailing areas was reported by Sunday Observer in $11^{\text {th }}$ March 2018 and the same newspaper noticed another RO plant project initiated by PINNA HILFE for Sri Lanka C.V. established in 1988 as an NGO under the funding of German based sources ${ }^{23}$.

The ministry of Health and local medicine took action to aware Dry Zone communities by introducing various $\mathrm{CKDu}$ preventing programs employed by Ayurvadic doctors as resource persons. The common characteristics of these programmes were lied on propagating over sustainable livelihood, indigenous knowledge of healthcare, traditional and healthy food habits, preventing artificial food and agrochemicals and many others. Various leaflets, potters, banners, and cutouts were appeared in programing premises and public spaces (Picture 1, $2 \& 3$ ). In addition to establishment of new Western health facilities and blood-transferring centers introduced into remote areas such as Medwachchiya, Ayurvedic hospitals took action to advance their capacity to treat kidney patients. While Ayuvedic doctors played significant role in terms of alleviating new pandemic, the contribution of established local medical reservoirs (Deseeya Chikitsa) was also remarkable in the process reducing bulk of residential hospitals. For instance, a local healer who specialized in kidney diseases was observed lived at Oyamaduwa in Vilachchiya that has been facilitating for 60 residential kidney patients in his home premises (Local dispensary).

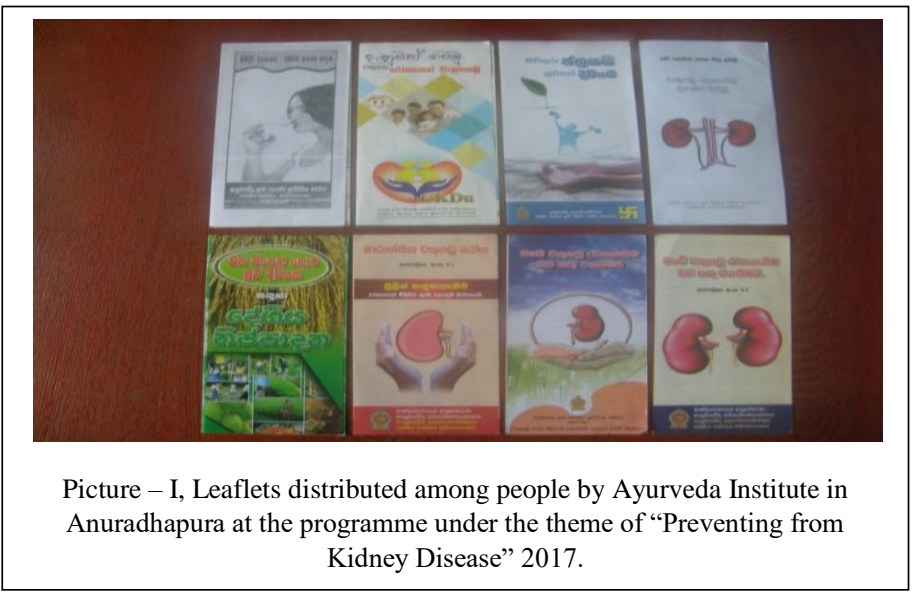

Picture 1

\footnotetext{
${ }^{21}$ www.hirunews.com (online access 11.02.2018)
}

\footnotetext{
${ }^{22} \mathrm{https}: / /$ sundayobserver.lk/

${ }^{23} \mathrm{https}: / /$ sundayobserver.lk/
} 


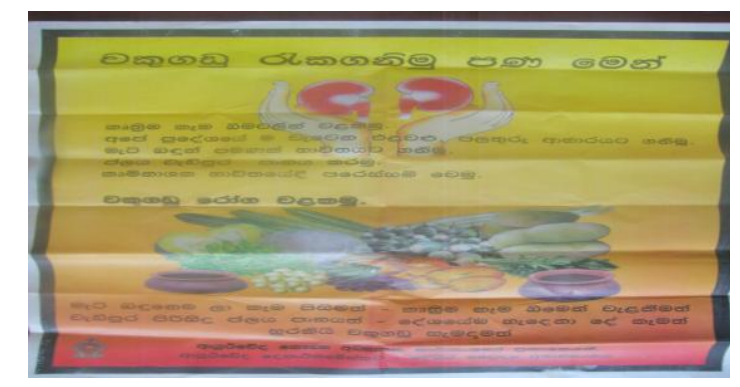

Picture - II, A poster that considers; "Let us take care of kidneys corresponding our life" 2017 Anuradhapura.

Picture 2

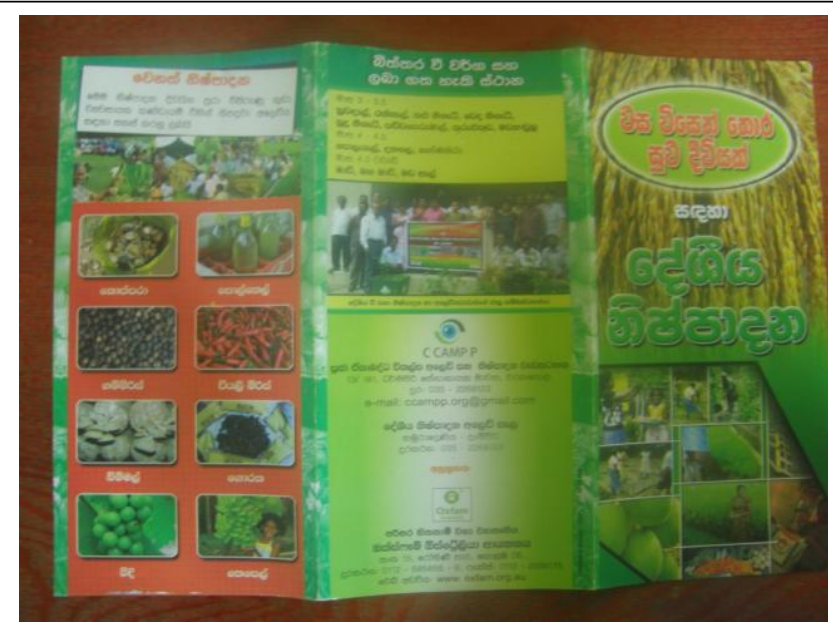

Picture - III, inside a leaflet that promotes 'Indigenous agro-products for healthy life'. 2017 Anuradhapura.

Picture 3

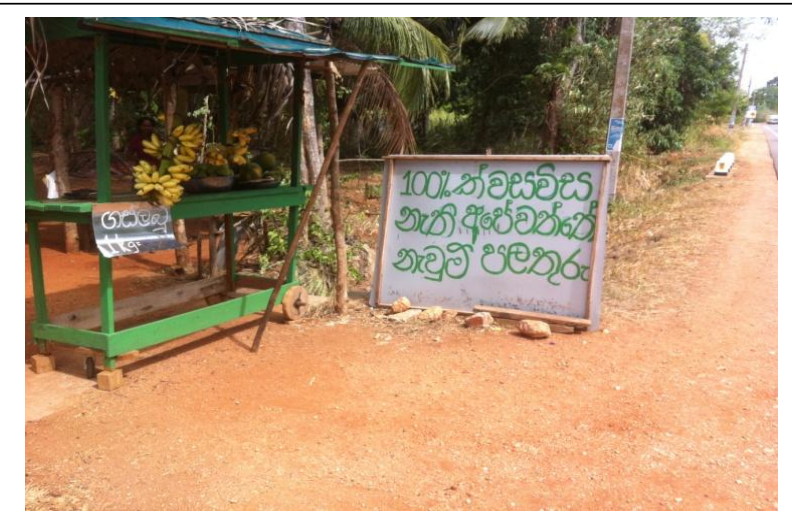

Picture - IV, Marketing of poisons-free fruits notifying " $100 \%$ arsenic-free home made fresh fruits" (Beside the ColomboAnuradhapura main road (Captured in $25^{\text {th }}$ May 2018).

Picture 4

The actions against agro-chemical fertilizations by ruling authorities in Sri Lanka is in process up to writing this article. President Gotabhaya Rajapaksha took a strong action to ban import all kinds of artificial agro chemicals while leading the
Island to fully organic agricultural system in the mid of 2021. This decision was stressed by him highlighting; "Hope more countries will be inspired by Sri Lanka's bold approach to organic agriculture..." addressing the UN Food Systems Summit 26-28 July 2021 in Rome ${ }^{24}$. The debate over pro and anti-agrochemicals is continuous in Sri Lanka while ramping criticisms by academics and scientists claiming the decision was taken by the government to ban artificial fertilizers is neither based on environmental contamination issue never sympathy of general public but as the result of burning crisis of lacking foreign income and repayable of foreign debts.

\section{Panic of Melamine and DCD}

The mass panicking over food contamination seems to be one of the latest trend in Sri Lanka. One aspect of food poisoning is concomitant by aforementioned glyphosate use, some other similar contentions as well show their association of similar panicking. Although, there are some distinct incidents available in historic chronic or folk lore regarding homicide providing poisonous food for the purpose of overwhelm of enemies or competitors, they seem to be desperately derivative in individual and specific circumstances. Considering to glyphosate and melamine panics, though they embody different social contexts, the both are derived from the same roots. Firstly, the idea took place on 2008 with popularizing milk powder imported from China is contaminated by artificial ingredient calls melamine. Although, there was none of idea on melamine among general publics at the beginning, it was a huge controversy followed by media proliferation. Lanka Business Online webpage reported on $17^{\text {th }}$ October 2008, Sri Lanka's Health Ministry has banned the import and sale of 60 food products as a precautionary measure following the melamine Chinese milk contamination scandal. The products include milk powder and those using milk as an ingredient such as chocolate and biscuits $^{25}$. Then the melamine panic was gradually disappeared as a result of immediate action taken by the government. Again a similar experience; the case of DCD (Dicyandiamide) $^{26}$ came to arena on the basis of test conducted by the Ministry of Technology and Research and carried out by the Industrial Technology Institute (ITI) the country's premier scientific and industrial research, revealed to media that DCD positive in some of milk products imported from New Zealand. Thereafter ITI had a meeting with the Government Medical Officers (GMO), Food and Drug Authority and Food Authority Committee on August $6^{\text {th }}$

\footnotetext{
24 https://www.presidentsoffice.gov.lk/index.php/2021/07/27/hope-morecountries-will-be-inspired-by-sri-lankas-bold-approach-to-organicagriculture/

${ }_{25} \mathrm{https}: / / \mathrm{www}$.lankabusinessonline.com/sri-lanka-banns=60-food-productson-melamine-fears/

26" Dicyandiamide (DCD), is a chemical compound used by farmers to reduce the negative effects of greenhouse gas emission and nitrate leaching into waterways. It has also been reportedly used by some to promote the growth of pastures where cows graze. Furthermore, dicyandiamide is a nitrogen-rich compound that is classified with compounds such as melamine as a potential economic food adulterant to enhance the apparent protein content of the food product" (Editorial, Sri Lanka Journal of Child Health, 2013; 42(2): 63-64).
} 
2013 and it agreed to have all batches of milk products produced by New Zealand based Fonterra Cooperative Group (FCG) remove market as soon as possible.

The Pressreader.com (19 ${ }^{\text {th }}$ August 2013$)^{27}$ online web page reported official action taken by authorities as are in the following:

\begin{tabular}{|c|c|c|c|c|}
\hline Aug 05, 2013 & Aug 06, 2013 & $\begin{array}{l}\text { Aug 07, } \\
2013\end{array}$ & Aug 16, 2013 & Aug 18, 2013 \\
\hline $\begin{array}{l}\text { Ministry } \\
\text { instructed the } \\
\text { customs to } \\
\text { immediately } \\
\text { suspend the } \\
\text { clearance of } \\
\text { milk powder } \\
\text { containing } \\
\text { whey protein } \\
\text { on health } \\
\text { concerns in } \\
\text { the wake of } \\
\text { China and } \\
\text { Russia } \\
\text { announcing a } \\
\text { ban on milk } \\
\text { powder } \\
\text { imports from } \\
\text { New Zealand. }\end{array}$ & $\begin{array}{l}\text { The Health } \\
\text { Ministry } \\
\text { notified all } \\
\text { milk powder } \\
\text { suppliers } \\
\text { whose } \\
\text { products were } \\
\text { suspected to } \\
\text { contain } \\
\text { dicyandiamide } \\
\text { (DCD) to } \\
\text { remove their } \\
\text { milk powder } \\
\text { items off store } \\
\text { shelves with } \\
\text { immediate } \\
\text { effect until } \\
\text { further notice. }\end{array}$ & $\begin{array}{l}\text { The } \\
\text { Director } \\
\text { General of } \\
\text { Health } \\
\text { Service has } \\
\text { requested all } \\
\text { print and } \\
\text { electronic } \\
\text { media heads } \\
\text { to suspend } \\
\text { commercials } \\
\text { on all milk } \\
\text { powder until } \\
\text { further } \\
\text { notice. }\end{array}$ & $\begin{array}{l}\text { Gampaha } \\
\text { District Court } \\
\text { issued an } \\
\text { enjoining } \\
\text { order } \\
\text { preventing the } \\
\text { New-Zealand } \\
\text { based dairy } \\
\text { giant Fonterra } \\
\text { Brands Pvt. } \\
\text { Ltd and its } \\
\text { Managing } \\
\text { Director from } \\
\text { selling, } \\
\text { distributing } \\
\text { and } \\
\text { advertising all } \\
\text { Fonterra } \\
\text { products in } \\
\text { Sri Lanka. }\end{array}$ & $\begin{array}{l}\text { The Industrial } \\
\text { Technology } \\
\text { Institute (ITI) } \\
\text { is now } \\
\text { planning to } \\
\text { test samples } \\
\text { of both } \\
\text { imported and } \\
\text { locally } \\
\text { produced- } \\
\text { fruits for } \\
\text { possible } \\
\text { contamination } \\
\text { with harmful } \\
\text { chemicals. }\end{array}$ \\
\hline
\end{tabular}

The same article quoted the Science and Technology Research Minister Patali Champika Ranawaka "We cannot allow our children to be used as 'Guinea Pigs' in this exercise for experiments". Many other significant individuals and social organizations made a magnitude discourse within mass media against unaccountability of the estate sector and depraved actions multinational companies. The general contents of paper articles of intellectuals and editorials were repeated emphasis of certain slogans such as 'malnutrition of future generations' and 'accelerating of non-communicable diseases that is already prevailed over the Island'. The obvious consequence of these statements was public denunciation of all kinds of imported milk powder products while concomitant demanding of locally manufactured milk powder brands. If this trend was systematically monitored, it could have been positively impact on the preservation of local market. However, all protesting campaigns left in vain as a result of inconvenience addressing demand factor. Both government and private sectors were not capable enough supplying to fill up huge vacuum of the market. On December $25^{\text {th }}$ in 2013 the Colombopage website reported "Severe shortage of milk powder in Sri Lanka" 28

At the same epoch, a strike took place at the state-owned Milco Company under the 'perfect timing' of worker-unions has affected the suppliers of locally produced Highland Brands. The long queues were appeared in front of both agents and retailors of locally manufactured milk powder brands. The retailors were in a trouble of supplying for the

\footnotetext{
${ }^{27} \mathrm{https}$ ://www.pressreader.com/sri-lanka/daily-mirror-sri-lanka

${ }^{28}$ www.colombopage.com/archive 138/Dec25/
}

uprising demand. They were constrained to hold back some packets on the purpose of maintaining the good will of their regular customers.

The bubbling uproar against DCD gradually disappeared with systematic transferring of same brand imported milk products in the market. There was a public supposition on that either of direct intervention of political authority of foreign exporters or conspiracy of corrupted multinational companies. However, the front line local politicians manufactured this hullaballoo had been frontiers of the general election of 2015 as well. Thereafter, the Daily FT.lk webpage reported under the title of "Parliamentary committee raises questions over milk powder, fruits and canned fish imports" on 5th April $2019^{29}$. The Committee on Public Accounts (CoPA) has tabled the second report of the third session of the eighth parliament containing information on 20 institutions examined during 23 February - 12th October 2018. The report has highlighted questionable import of milk powder from New Zealand and release to the market without conducting any laboratory test for melamine and other contaminations. However, all kinds of imported milk product are available in the market even today without any interruption.

\section{Panic of sterilization pills}

Compared to previous sources of moral panic, the masspanicking over the ingredient of sterilizing or anti-fertilizing formula in food, women underwear, and toys was extremely violence and politically tensioned series of incidents in Sri Lanka. It was stamped as a residual part of structuralized antiMuslim propagation among majority Sinhalese that gradually grown and came to its extreme level in 2018-2019. The panic came symbolically into arena on the form either of sterilizing pills or other methods, that depicted the controversy has been derived from the general attitude that on speedy rates of increasing of Muslim population and taking over the trade authority throughout the Island (Silva, 2019). Moral engineers behind the propagation were cultural and political elites including mass-holders of the business sector (Silva, 2020). For instance, at the period 2013, there had been a huge campaign particularly based on social media against Muslimowned business places such as Fashion Bug, No-Limit etc. claiming that they were selling underwear flavoured in sterilizing cream, and the same rumor has been popularized again in 2018 on top. (Bhuiyan, 2019). This author experienced throughout this period, a rumor that considered the toys such as balloons that distributed among kids by aforesaid mall shopping centers and popular places such as KFC, Pizza Hut are consisted off poisoned fume that could be occurred enduring sterilization. Rameez (2018) sorted out factors those were behind panic on "Islamization" in Sri Lanka such as panic of growing population of Muslims, myth of sterilizing pills, economic rivalry and jealousy, common Islamaphodia, formation of racial political party for Muslims and exceptionalism to Buddhist clergies.

\footnotetext{
${ }^{29}$ https://www.ft.lk/Business/Parliamentary-committee-raises-questions-overmilk-powder-fruit-and-canned-fish-imports/34-676018
} 
The sterilizing pills panic that has been projected into the conscious of general public caused building a huge anxiety within Sinhalese majority in particular. The news in dailies and social media reported them elaborately and sometimes exaggeratedly. For instance, the Muslims-owned pharmacy contained vast amount of tablets used in abortion that raided by police, an ethnic Muslim who sold illegal drugs targeting of school children etc. However the reactions over these rare or general to ethnic ratio or sometimes fabricated news has been flickering out in various forms and different occasions during the recent past in Sri Lanka. Hence, the most hysterical and pathetic incident among these took place on $25^{\text {th }}$ February 2018 in a Muslim-owned eatery called 'New Kassim Hotel' situated in Ampara town in Eastern Province; $360 \mathrm{~km}$ from Colombo. According to media reports, the owner A.L. Farsith has been making food for customers. According to request of Sinhalese customer he has been taking action to prepare a kottu rotti. When he was adding necessary ingredients such as salt, spicy etc. the customer has questioned that "did you add wandapethi?" Farsith who was making kottu rotti had never idea of this strange Sinhalese terms has nodded accepting it. Later, as he stated to media "My Sinhalese is not very good. I had never heard the term 'wandapethi' before. I was afraid for my life, so I just nodded and said yes, ${ }^{, 30}$ This incident was videoed by somebody and released to social media. A mosque, lodging place adjoining it, several small shops laid closed proximity, a street-side hotel and several vehicles, all belonging to Muslims was set fire $^{31}$

Although, the rudimentary incident was rather unpretentious as much as ignorable compare to various conflicts occurred between a pair or groups, the final outcome made a huge damage to the humanity and black mark to the social history of Sri Lanka. The violence against to the Muslim-owned business places, private houses and religious spaces erupted first in Ampara town on 26/27 $7^{\text {th }}$ February 2018 night. It seems to be taken around one week to fabricate stories and spread rumors towards other part of the country. The followed by attacks were befallen in Kandy on $4^{\text {th }}$ March and spread to other areas in Kandy District like Teldeniya, Pallekele, Katugastota and Akurana etc. The least damage in Ampara compare to the destruction in Kandy showed the magnitude of accomplishment of the inevitable duty of moral entrepreneurs in ethno-political sector in Sri Lanka. The total damage caused by the circumstance has been calculated that about nearly 465 houses, businesses and vehicles were destroyed and promised to compensate for the families who were severely affected due to the communal violence ${ }^{32}$.

The public anxiety on the Muslims which were created, imagined or based on falls factors suddenly became a real

\footnotetext{
${ }^{30}$ http://www.sundayobserver.lk/2018/03/04/news/tension-ampara-after-fake$\%$ E2\%80\%98sterilization-pills\%E2\%80\%99-controversy

${ }^{31} \mathrm{https} / / /$ colombogazette.com/2018/02/27/ampara-tense-following-attack-onshop-and-mosque/

http://www.dailymirror.lk/article/Kandy-incidents-created-newinternational-challenges-PM-147104.html
}

with the notorious Easter Sunday bloody attack occurred on $21^{\text {st }}$ April 2019. A total of 269 people were killed in addition to more than 500 people were injured in a series of coordinated Islamic extremist group's suicide bombing three churches in Sri Lanka and three luxury hotels in the capitalColombo $^{33}$. Although, it has been a blunder of a terrorist group, it mechanically provided strong slogans to anti-Muslim activists to line up their political agenda. It is doubtless that this incident was the turning point of fall the then hybrid government led by President Mithreepala Srisena the chief of Sri Lanka Freedom Party and Prime Minister Ranil Wickramasinhe the leading of United National Party. This controversy led up to the historic winning of President Gotabhaya Rajapaksha by the election held in $16^{\text {th }}$ November 2019.

\section{Panic of Unauthorized satirizing surgery}

Immediate post-Easter attack, the 'Safi Shihabdeen panic' made a huge disturbance among general publics which claimed that a Muslim doctor Shegu Shihabdeen Mohammed Shafi have satirized more than 4,000 Sinhalese women during their medical treatment ${ }^{34}$. Corresponding to the report of Divaina newspaper, Dr. Channa Jayasumana revealed Dr. Shihabdeen's identity via his Facebook account. His interpretation inserted academic justification to the rumor. Dr. Shihabdeen was a senior house officer in gynecology and obstetrics at the Kurunegala Teaching Hospital (KTH). Meantime, he has been a member of the All Ceylon Makkal Congress (ACMC) which campaigned under the United National Party (UNP) in 2015 general election. Even though, he secured 54,000 votes, as well as 8th place in the list of candidates, was not elected to the parliament on the basis of preferential votes received. After his election defeat, Dr. Shihabdeen has appealed to the Ministry of Health to be reinstated at the hospital and he was restored followed by cabinet approval (Ibid).

The controversy over unauthorized satirizing was endured some period on the peak and slight resolution among people after promising to take action for a formal investigation about the incident by the government. As a result, a committee that made up of medical specialist has been appointed. However, a huge sound derived again contrary to testing of victimized mothers that claiming the test would be harmful for mothers and may be caused of further damage to Fallopian tubes. Bandaranaike and Nicolle (2020) systematically present this story a step at a time from stand point of the storm to the granting bail of Shihabdeen by Kurunegala Magistrate's Court in $25^{\text {th }}$ July 2019. Even after the origin of the major racket of Dr. Segu Shihabdeen case, some other related sub incidents appeared in several forms. Several times the mothers who claimed that they were victimized to uninformed satirizing by VOG Shihabdeen had been organized demanding systematic investigation on the incident. For instance, a series of protests with the participation of so-called mistreated mothers for

\footnotetext{
${ }^{33} \mathrm{https}: / /$ thediplomat.com/tag/sri-lanka-easter-sunday-terrorism/

${ }^{34}$ Daily Divaina May 23, 2019.
} 
"damaging fallopian tube" by Dr. Shihabdeen were taken placed. Ven. Athuraliye Ratana has been again among the top who staged against to satirizing of Sinhalese mothers. Plenty of press statements made by pro-protesters were forecasted by visual and nonvisual media. Some media played a remarkable role to popularize the case Island wide. The idiomatic phrases such as "shafi-sāpaya" (Curse of Shafi) may be a salient example of the eloquent of the Sinhala language to create powerful placards or slogans that used by even as the heading of the editorial of a local newspaper to show their aggression against to "satirizer".

The medical doctor as well as academic Professor Channa Jayasumana was revealed confirming his nomination to compete for the general election under newly established political party: pohottuwa (the popular name of Sri Lanka People's Party (SLPP)). He was also a prominent member of 'Viyath Maga' made up of academics, public servants and traders etc. which made a considerable involvement to President Gotabhaya Rajapaksa's election campaign. The hanging in a popular racial issue makes many avenues to move forward at the power ladder of Sri Lanka politics. The popularization of the name that attached to Segu Shihabdeen incident, medical doctor Sarath Weerabandara; former Director to the Central Hospital of Kurunegala may be one of the salient example to prove that the racial controversy to be used by "insightful" people for their power dealing process. Dr. Weerabandara stepped forward to take his supreme actions provoking of the controversy generated due to socalled satirizing Sinhalese women by Dr. Segu Shihabdeen. $\mathrm{He}$ criticized inefficient action of Kurunegala police station against to Shihabdin. As the Director of the hospital Dr. Weerabandara not promoted relevant authorities to take immediate legal action against to accused but also motivated mothers to complaint on malpractices committed by Dr. Shihabdeen that took place during their delivering period.

However, the underground plot that was manipulated by indefinite supremacy has been questioned within legal circumstance as well. Once the case was taken up at the Kurunegala Magistrate's Court on $9^{\text {th }}$ August 2019, the lawyers of suspect claimed that whole project is as a 'Phottuwa's conspiracy'. They further mentioned that "At the beginning of this drama, we revealed that the incident involving Dr. Safi is a conspiracy of the SLPP, and Sarath Weera Bandara is a disciple of MP Wimal Weerawansa. Weera Bandara is footing above the judiciary by using the political power. The drama is being scripted by Weerawansa; a drama that incites racism in the coming elections and aims to win votes." ${ }^{35},{ }^{36}$ This strong accusation was justified by post-incidents took place in several occasions. The nomination to compete forthcoming general election of Dr. Channa Jayasumana representing SLPP of the Kurunegala

\footnotetext{
${ }^{35} \mathrm{https} / / / \mathrm{www}$. lankanewsweb.net/66-special-news/47095-Safi\%E2\%80\%99scase:-Sarath-Weera-Bandara-who-stands-above-law

36 https://www.colombotelegraph.com/index.php/shafi-saga-kurunegalahospital-director-dr-weera-bandara-misleads-court-tantamount-to-contempt/ (10th August 2019 Colombo Telegraph)
}

District was revealed by media in the end. Solid attempts to nominate the name of Dr. Weerabandara to the same election appeared in many forms. The image he could built by provoking the Shehabdeen incident has been used demanding in every occasion. For instance, According to Divaina newspaper in $2^{\text {nd }}$ February $2020^{37}$, a special assembly of Buddhist clergy gathered at Kurunegala Athkanda Vihara tempal premises came to the conclusion that to promote Dr. Sarath Weerabandara to the forthcoming parliament election. The gathering of around one hundred Buddhist clergies belonging to all three nikayas were led by the prominent Buddhist monks in the area such as chief of Ussawa-Kagala Royal Temple, Waraddhana Dhammananda thera and the chief of Ganewatta Sumangala Vihara, Atamune nayaka thera. The newspaper further reported Dr. Weerabandara sent a petition signed by 5000 people including mothers who lost their babies due to surge by Dr. Shihabdeen and other staff members of the Kurunegala hospital to the President requesting put his name into SLPP nominee list to compete to the election. Even though, no evidence to consider that Dr. Weerabandara has been nominated as a candidate to the general election, he was succeeded securing his position (which was terminated by the previous government) to direct the Kurunegala Central hospital after electing of new SLPP government ${ }^{38}$. This popular "satirizing surgery case" is being probed in the Sri Lankan Supreme Court up to the time of writing this article.

\section{CONCLUSIONS}

The deliberate or insentient socialization of moral panic is a common phenomenon of many communities in the world. It sometimes would appeared in a form of religious or another structuralized social need. When it is searching the roots that to be patronage of these panics, some are based on real phenomena, some may be founded by certain stand of real that highly fabricated and exaggerated factors, and the third sort may be utterly baseless social constructions. Printed, electronic and all other digitalized social media play a significant role in popularizing these sorts. The common intended outcome of all these attempts are spreading shock in the society. If an individual or a group makes deliberate attribution of insertion panic within masses means he or they may have an unrivaled political agenda rather than general empathy of the other. Considering to recently appeared controversies in Sri Lanka, they show the characteristics of fabrications that signs authenticity while majorly constructed semi-factors and those which are grounded by doubtless falls rumors. The politicians, cultural elites and some pressure groups that seek fulfilling their hidden political agendas can be seen as vital actors as moral engineers and moral entrepreneurs. So-called mass media and uncensored social media users knowingly or unknowingly has carried out the

\footnotetext{
${ }^{37} \mathrm{https}: / /$ divaina.lk/20.02.2021

${ }^{38} \mathrm{http}: / /$ colombotimes.net/transfer-order-of-director-of-kurunegala-hospitalreversed/ ( $15^{\text {th }}$ May 2020 Colombo Times)
} 
needs of those groups. Whereas, Sri Lanka may be a salient field to those who are testing hypothesis on moral panic that were developed by pioneers of the stated context.

While being existence of a strictly structuralized system of moral panic that is operative from the stand point of the process of socialization in Sri Lanka, they have been utilized with association of mere religious determinations and means of achieving certain goals of social control with minor effect. However, more recently developed and further alive social movements seems to be manipulated by operative political factors and situations that created by them are solid with extreme harm and violence. As an instead, the chronic kidney disease prevailed over the Dry Zone is an obvious pathetic situation, the tragedy made by conscious groups on the issue such as politicos, patriots, researchers, media-men, paid writers has pressed the society over towards immense gloomier hedge. The direct sufferers as well as outsiders are in a doubt on consuming all kinds of daily food items and agrochemicals. The created ambiguity about intoxication of food, exceptional demand has been generated for "toxic-free" label of common fruits and vegetable of the market. The bottled water consumption has been ascribed a special superiority meantime struggled to deal with newly emerged shopper culture. Politicians and policy makers are being without stand under multiple phase of internal and external pressure.

The melamine and DCD panic has been operated within patriotic political actors, as a salient tool that would paved the way to power. The too early launched "melamine panic" against Fonterra productions even without proper arrangement to manufacture adequate amount and without credibility to enhance alternative supply chain created astonished situation in the Island. General publics were in a trouble with loosing habitual food style of everyday life. The unusual demand for locally produced milk powder created long queues in front of retail as well as stock sales centers. Both sellers and consumers were in a distress on maintaining goodwill among each other.

The satirizing pills and satirizing surgery fright were comparatively horrific and destructive manufacture which has been released later to the general consumers by cultural and political moral entrepreneurs. It may not be underestimated about those careful role played by mainstream political elites behind the screen by using uprising sectarian patriotic movements. The planted idea that of fast-increasing Muslim population may cause for change the concurrent rates among ethnic groups and it may lead to gradual deduct majority Sihalese population has been fuelling to develop this situation for a long period. The changed voting decision of the majority Sinhalese at the immediate (2019) Presidential Election and the land slight victory of Sri Lanka People's Freedom Alliance (SLPFA) at 2020 general election using votes of the same group depicts the effective of this propaganda. The allegation of several anti-satirizing pills and anti-satirizing surgery chauvinist with the concurrent ruling party at the peak of the general election reveled the hidden sponsorship of the moral engineering of those panics.

\section{REFERENCES}

[1] Amenta, Edwin; Neal Caren; Elizabeth Chiarello (2010) Political Consequence of Social Movements, Annual Review of Sociology, www.annualreview.soc (Online Open Access, Last View: $15^{\text {th }}$ Feb. 2020)

[2] Bandarage, Asoka (2013), Political Economy of Epidemic Kidney Disease in Sri Lanka, Sage Open (November, 2013), https://doi.org/10.1177/2158244013511827 (Online Open Access, Last View: $15^{\text {th }}$ Feb. 2020)

[3] Bandaranaike, A.D. \& Nicolle, S. 2020. Information Disorder and Mainstream Media in Sri Lanka: A Case Study, Social Media, Disinformation and Democracy in Asia: Country Cases, Seoul, Asia Democracy Research Network: pp. 267-292.

[4] Bide, Yalena Margatete (2015) Social Movements and Process of Political Change: The Political Outcome of the Chilean Student Movement; 2011-2015, Brown University Providence RI, the Watson Institute for International Studies.

[5] Bhuiyan, Md Kamruzzaman (2019) The Bloody Easter Sunday Terrorist Attack in Sri Lanka: What Went Wrong?, IOSR Journal of Humanities and Social Science, Vol. 24, Issue 9, Series 8 (September, 2019), 35-40.

[6] Cohen, Stanley (2002). Folk Devils and Moral Panics: The Creation of the Modes and Rockers. London and New-York, Rutledge.

[7] Cooray, Titus; Yuansong Wei 1,2,3,* , Hui Zhong 1,2, Libing Zheng; Sujithra K. Weragoda and Rohan Weerasooriya (2019), Assessment of Groundwater Quality in CKDu Affected Areas of Sri Lanka: Implications for Drinking Water Treatment, International Journal of Environmental Research and Public Health, 2019, 16, 1698; doi:10.3390/ijerph16101698 (Access: 12.1.62019)

[8] Critch, Chas (2018). Moral Panic Analysis: Sociology Compass, Vol. 2, Issue 4, July 2008 (Ed. Rebecca Kissane and ulie Kmec), ISSN 1751-9020.

[9] Dalton, Russel J. and Hans-Dieter K. (2013) Overview of Political Behaviour: Political Behaviour and Citizen's Politics, The Oxford Handbook of Political Science, (Ed. Robert E. Goodin), Online Open Access, (Last View: $13^{\text {th }}$ Feb. 2020).

[10] De Silva, A.M.W; Albert, Steven M.; Jayasekar, J.M.K.B. (2017). Structural violence and chronic kidney disease of unknown etiology in Sri Lanka, Social Science \& Medicine, Volume 178, April 2017, Pages 184-195, https://doi.org/10.1016/j.socscimed.2017.02.016

[11] Dissanayaka, Suneetha \& Silva, Gihani De (2017). Sabaragamuwa University Sinhala Shasthiya Samgrahaya, Vol. 10, Sabaragamuwa University of Sri Lanka

[12] Faundes, J.M.M. 2019. The geopolitics of moral panic: The influence of Argentinian neo-conservatism in the genesis of the discourse of 'gender ideology', International Sociology. 2019;34(4):402-417. doi:10.1177/0268580919856488

[13] Goode, Erich \& Ben-Yahuda, Nachman (1994) Moral Panic, Culture, Politics and Social Construction, Annual Review of Sociology, No. 20, 149-171.

[14] Hill, Michael (2001). Elite Sponsored Moral Panic: A Singapore Perspective, CAS Research Paper Series, No. 33, National University of Singapore, Centre for Advanced Studies.

[15] Hill, Michael (Undated). Conversion and Subversion: Religion and the Management of Moral Panics in Singapore, Working Paper 8, Asia Studies Institute, Victoria University of Wellington.

[16] Holland, Jennet; Cardin, Ramasanoglu; Sue, Scott (1990). AIDS: From Panic Station to Power Relations Sociological Perspective and Problems, Sociology Vol. 25, No. 3, 1990, SAGE.

[17] Jayalal, Ananda T.B, (2015). Chronic kidney disease of uncertain aetiology: adding vital piece of information to the national project team report of Sri Lanka, BMC Nephrology, 16, 216 (December), https://doi.org/10.1186/s12882-015-0211-5 (Access: 12.1.62019)

[18] Jayasekara, J.M.K.B.; Menike, D. Dammika; Adhikari, Badri (2013), Geographical distribution of chronic kidney disease of unknown origin in North Central Region of Sri Lanka, Ceylon Medical Journal (March 2013), 58(1):6-10, DOI: 10.4038/cmj.v58i1.5356 (Access: 19.10.2018) 
[19] Marambe, Buddhi (2019). Banning of herbicides and the impact on agriculture: the case of glyphosate in Sri Lanka, Weed Science , Volume 68 , Issue 3 , May 2020 , pp. 246 - 252, DOI: https://doi.org/10.1017/wsc.2019.71 (Access: 19.10.2020)

[20] Mendley, Susan R.; Adeera Levin; Ricardo Correa-Rotter; Madeleine K. Scammell; Robert O. Wright; Robert A. Star, (2019). Kidney International, VOLUME 96, ISSUE 5, P10711076, (August

2019), DOI:https://doi.org/10.1016/j.kint.2019.06.024, ， (Access: 22.01.2020)

[21] Obeyesekere, Gananath (1977) Psycho-cultural Exegesis of a Case of Spirit Possession in Sri Lanka. In Case Studies in Spirit Possession. V. Crapanzano and V. Garrison, ed. pp. 235-294. New York: J. Wiley.

[22] Rajapakse, Senaka; Chrishan, Mitrakrishnan; Shivanthan, and Selvarajah, Mathu (2017). Chronic kidney disease of unknown etiology in Sri Lanka, International Journal of Occupational Health, 2016 Jul; 22(3): 259-264: doi: 10.1080/10773525.2016.1203097 (Access: 22.10.2020)

[23] Rameez, Abubaker (2018) Resurgence of ethno-Religious Sentiments Against Muslims in Sri Lanka: Recent Anti-Muslim violence in Ampara nd Kandy, Journal of Politics and Law, Vol. 11, No. 4, 2018
[24] Rocheron, Yvette and Linne, Olga (1989). European Journal of Communication, Vol. 4, Issue 4, Dec. 1989, SAGE.

[25] Silva, K.T. 2019. Religious Diversity and Interreligious Contestations in Sri Lanka: The Encounter between Buddhism and Islam in the Galebandara Cult in Kurunagala eligious diversity in Asia, Religious Diversity in Asia (Ed. Borup, J. et al.), Leiden/Boston, Brill, pp. 243-267.

[26] Silva, K.T. 2020. Stigma and Moral Panic about COVID-19 in Sri Lanka, Journal of Humanities and Social Sciences (JHS), Volume 03, Issue 02, University of Peradeniya, PGIHS.

[27] Ugwuoke, C.O., Ngwu, E.C. \& Iziga, P.N. 2016. Terrorism and Moral Panic in Nigeria, Review of European Studies; Vol. 8, No. 3; 2016 ISSN 1918-7173 E-ISSN 1918-7181 Published by Canadian Center of Science and Education.

[28] Waxler, Nancy E. (1976) Social change and psychiatric illness in Ceylon: An investigation of traditional and modern conceptions of disease and treatment. In Culture Bound Syndromes, Ethnopsychiatry and Alternative Therapies. W. Lebra, ed. Honolulu: pp. 22-240.University of Hawaii Press.

[29] Waxler, Nancy E. (1977). Is Mental Illness Cured in Traditional Societies? A Theoretical Analysis, Culture, Medicine and Psychiatry, No. 1, pp. 233-253 